\title{
Contribution of Rainwater Harvesting in Agriculture of Gujarat: A Case Study of Ahmadabad District
}

\author{
Nilu Khan \\ Research Scholar, Centre for Studies in Economics \& Planning, School of Social Sciences, Central University \\ of Gujarat, India
}

\begin{abstract}
Rainwater harvesting $(R H)$ is a new technique to conserve water and later use them in irrigation and other purposes due to growing urbanization and increasing population. Popularizing this technique in Gujarat, the credit goes to the Saurashtra Lok Manch Trust (an NGO) which works, studied the system and prepared the literature to educate farmers and other people that how to conserve water. The discharge of water from Sardar Sarovar reservoir through canals in recent years has boosted the agricultural production in a few districts of south (Bharuch, Baroda and Narmada) and north Gujarat (Ahmadabad and Gandhinagar). Now-a-days water harvesting system has been installed in most states of India because there are many benefits of adopting it such as increase in water availability, checks the declining water table, avoids flooding, improves the quality of groundwater through the dilution of fluoride and prevents soil erosion etc. Therefore, this study is focused on the contribution and role of $R H$ in Gujarat Agricultural (by showing improvement in land productivity and increase in crop production). The data for the study is collected by conducting the primary survey through using the schedule technique and focused group discussions. On the other hand, the data is also collected from the secondary sources like official website, books, research papers, journals etc.
\end{abstract}

Keywords: Drought, Water Scarcity, Irrigation Facility, Check Dam, Agricultural Production

\section{Introduction}

Rainwater harvesting is a process of direct collection of precipitation falling on the roof or on the ground for productive purposes (like agricultural and human use related to water). Because the runoff water causes erosion so it is harvested and utilized and considered as a rudimentary form of irrigation. RH is usually treated as an umbrella which describes the whole methods of collection and runoff forms such as rooftop runoff, overland flow, stream flow etc. from rainfall. From the past few years water harvesting (WH) has become essential because the surface water is inadequate to meet the growing demand of human beings. Due to rapid urbanization the infiltration of rainwater into the sub-soil has decreased drastically and as a result the recharging of groundwater has reduced. The process of WH is applied in arid and semi-arid regions where rainfall is either not sufficient to sustain a good crop or in the region where due to erratic nature of precipitation, the risk of crop failure is very high. RH has played a very important role for the well-being of people and agriculture in dry areas. The reason for that there is no pumping from groundwater, facility of check dams and convenience of water through lined canals, pipes etc. On the other hand, the rising cost of water as well as the ecological concerns; have also resulted to accept the rainwater as a solution for water scarcity. India is the second country in the world that accounts for the highest precipitation levels. On an average $1200 \mathrm{~mm}$ of rainfall is received in the country with the maximum and the minimum of $19000 \mathrm{~mm}$ in Cheerapunji and 200-300 in Rajasthan respectively. But with the increase in industrialization; the 70 per cent of inland water has been contaminated due to industrial sewage. For example- Yamuna River in Delhi is polluted with coliform (Meghashyam, 2005). As a reason, in many states there are acute water crises so to tackle with this problem the water harvesting not only needs to be mandatory in the country but should be treated as an authoritative mechanism. In capital city i.e. Delhi the RH has become necessary for all new constructions. Today, the wheel of life and progress depends on water as because about 85 per cent of the drinking water requirements of villages and 33 per cent of the needs of urban areas are met by the exploitation of groundwater. Similarly, 50 per cent of irrigation is also done through groundwater (Inderjeet, 2009).

Water harvesting is only possible when there is a good monsoon. Most of the rainfall in India comes from the seasonal precipitation for example-The Himalayan region receives rainfall which accumulates in winter and melts in subsequent months. This gives rise to a second peak in the discharge of the rivers emanating from the Himalaya. The annual snowfall in the Siwaliks (foothill region of Himalaya) is of $3 \mathrm{~m}$. On the other side, the Pir Panjal and in lesser Himalaya the snowfall is of 15m (Allan, 1995). However, in other parts of country like Tamil Nadu and some adjacent parts of Kerala receive rainfall in winter months. About 60 per cent of the rainfall in Tamil Nadu occurs during October to December. So, it has been observed that about 75 per cent of rain occurs in the season June to September, 10-11 per cent rain in the post-monsoon season i.e. October to 
December, 3-4 per cent in winter months (January-February) and rest of 10-11 per cent in the pre-monsoon season from March to May (Patel, 2009).

Table 1: Water balance of India

Source: CSE, 2012

\begin{tabular}{|l|l|l|l|}
\hline S.N. & Category & $\begin{array}{l}\text { Absolute Qnt. in } \\
\text { mhm }\end{array}$ & Percent \\
\hline 1 & Precipitation (Rainfall + Snowfall) & 400 & 100 \\
\hline 2 & Surface storage and runoff & $115+45^{*}=160$ & 40 \\
\hline 3 & Evaporation & $70+5+10=85 \#$ & 21.25 \\
\hline 4 & Soil moisture + groundwater recharge $* *$ & 155 & 38.75 \\
\hline
\end{tabular}

Note:

Average annual rainfall $=1.194$ meters, Total area $=328$ million hectares

*-Runoff in the form of regenerated flow

\#-5 mhm from surface water and $10 \mathrm{mhm}$ from the soil moisture is lost through evaporation. $70 \mathrm{mhm}$ is lost directly through evaporation.

**-Out of this $50 \mathrm{mhm}$ is assumed as groundwater recharge. The soil moisture is annually used up in evapotranspiration.

Above Table 1 highlights the water balance in India throughout the year and therefore it is assumed that there is no depletion in the endowment of water resources. The level of water harvesting in different states has been shown in the Table below.

Table 2: Average annual rainfall of the states of India

\begin{tabular}{|c|c|c|c|}
\hline S.N. & State & Meteorological Divisions & $\begin{array}{l}\text { Average } \\
\text { Annual } \\
\text { Rainfall } \\
(\mathbf{m m})\end{array}$ \\
\hline 1. & $\begin{array}{l}\text { Andaman and Nicobar } \\
\text { Islands }\end{array}$ & Andaman and Nicobar Islands & 2,967 \\
\hline 2. & Arunachal Pradesh & Arunachal Pradesh & 2,782 \\
\hline 3. & Assam & Assam and Meghalaya & 2,818 \\
\hline 4. & Meghalaya & Assam and Meghalaya & 2818 \\
\hline 5. & Nagaland & Nagaland, Manipur, Mizoram and Tripura & 1,881 \\
\hline 6. & Manipur & Nagaland, Manipur, Mizoram and Tripura & 1881 \\
\hline 7. & Mizoram & Nagaland,Manipur,Mizoram,Tripura & 1881 \\
\hline 8. & Tripura & Nagaland, Manipur, Mizoram and Tripura & 1881 \\
\hline 9. & West Bengal & $\begin{array}{ll} & \text { Sub-Himalayan West Bengal and Sikkim } \\
\text { - } & \text { Gangetic West Bengal }\end{array}$ & $\begin{array}{l}2739 \\
1439\end{array}$ \\
\hline 10. & Sikkim & Sub-Himalayan West Bengal and Sikkim & 2739 \\
\hline 11. & Orissa & Orissa & 1489 \\
\hline 12. & Bihar & $\begin{array}{ll}\text { - } & \text { Bihar Plateau } \\
\text { - } & \text { Bihar Plains }\end{array}$ & $\begin{array}{l}1326 \\
1186\end{array}$ \\
\hline 13. & Uttar Pradesh & $\begin{array}{ll}\text { - } & \text { Uttar Pradesh } \\
\text { - } & \text { Plain of West Uttar Pradesh } \\
\text { Hills of West Uttar Pradesh }\end{array}$ & $\begin{array}{l}1,025 \\
896 \\
1,667\end{array}$ \\
\hline 14. & Haryana & Haryana, Chandigarh and Delhi & 617 \\
\hline 15. & Delhi & Haryana, Chandigarh and Delhi & 617 \\
\hline 16. & Chandigarh & Haryana, Chandigarh and Delhi & 617 \\
\hline 17. & Punjab & Punjab & 649 \\
\hline 18. & Himachal Pradesh & Himachal Pradesh & 1215 \\
\hline 19. & Jammu and Kashmir & Jammu and Kashmir & 1011 \\
\hline 20. & Rajasthan & $\begin{array}{ll}\text { - } & \text { West Rajasthan } \\
\text { - } & \text { East Rajasthan } \\
\end{array}$ & $\begin{array}{l}313 \\
675\end{array}$ \\
\hline 21. & Madhya Pradesh & $\begin{array}{ll}\text { - } & \text { Madhya Pradesh } \\
\text { East Madhya Pradesh }\end{array}$ & $\begin{array}{l}1,017 \\
1,338\end{array}$ \\
\hline 22. & Gujarat & $\begin{array}{ll}- & \text { Gujarat region } \\
- & \text { Saurashtra and Kachchh }\end{array}$ & $\begin{array}{l}1,107 \\
578\end{array}$ \\
\hline 23. & Goa & Konkan and Goa & 3,005 \\
\hline 24. & Maharashtra & $\begin{array}{ll}\text { - } & \text { Konkan and Goa } \\
\text { - } & \text { Madhya Maharashtra } \\
\text { - } & \text { Marathwada } \\
\text { - } & \text { Vidarbha }\end{array}$ & $\begin{array}{l}3005 \\
901 \\
882 \\
1034\end{array}$ \\
\hline
\end{tabular}


Contribution of Rainwater Harvesting in Agriculture of Gujarat: A Case Study of

\begin{tabular}{|c|c|c|c|}
\hline 25. & Andhra Pradesh & $\begin{array}{ll}\text { - } & \text { Coastal Andhra Pradesh } \\
\text { - } & \text { Telengana } \\
\text { - } & \text { Rayalaseema } \\
\end{array}$ & $\begin{array}{l}1,094 \\
961 \\
680 \\
\end{array}$ \\
\hline 26. & Tamil Nadu & Tamil Nadu and Pondicherry & 998 \\
\hline 27. & Pondicherry & Tamil Nadu and Pondicherry & 998 \\
\hline 28. & Karnataka & $\begin{array}{ll}\text { - } & \text { Coastal Karnataka } \\
\text { - } & \text { North Interior Karnataka } \\
\text { - } & \text { South Interior Karnataka } \\
\end{array}$ & $\begin{array}{l}3,456 \\
731 \\
1,126 \\
\end{array}$ \\
\hline 29. & Kerala & Kerala & 3055 \\
\hline 30. & Lakshadweep & Lakshadweep & 1515 \\
\hline
\end{tabular}

Source: Average Rainfall of States in India, 2013

Rainfall is a significant factor in hydrological cycle which varies spatially and temporarily. Although the monsoon affect most part of India as the amount of rainfall varies from heavy to scanty. There is high regional and temporal variation in the distribution of rainfall in India. Over 80 per cent of the annual rainfall is received in the four rainy months i.e. from June to September. According to the above table the annual receiving states are explained under four categories.

1.1 Areas of Heavy Rainfall $($ Over $200 \mathrm{~cm})$ : The highest rainfall occurs in west-cost on the WesternGhats as well as in the Sub-Himalayan areas in North East and Meghalaya Hills. On other side the Assam, West Bengal, West Coast and Southern slopes of eastern Himalayas receives heavy rainfall throughout year.

1.2 Areas of Moderately Heavy Rainfall $(\mathbf{1 0 0 - 2 0 0} \mathbf{~ c m})$ : This type of rainfall occurs in Southern Parts of Gujarat, East Tamil Nadu, North-eastern Peninsular, Western Ghats, eastern Maharashtra, Madhya Pradesh andOrissa.

1.3 Areas of Less Rainfall (50-100 cm): Upper Ganga valley, eastern Rajasthan, Punjab, Southern Plateau of Karnataka, Andhra Pradesh and Tamil Nadu receives the less rainfall throughout the year.

1.4 Areas of Scanty Rainfall (Less than $50 \mathrm{~cm}$ ): Northern part of Kashmir, Western Rajasthan, Punjab and Deccan Plateau. This occurs because rainfall is erratic and unpredictable.

The Indian Meteorological department (IMD) divides the year into four seasons in India that is named as winter, pre-monsoon, south-west and post-monsoon season. Division of these four seasons depends upon Monsoon pattern.

\section{Review of Literature}

As there have been several studies conducted on rainwater harvesting all around the world. From the existing literature, some have been discussed below in order to validate the proposed topic:

Arjun \& Neil (2009) in their article "Harvesting Rainwater: Catch Water Where it Falls" emphasized the need of RH. They pointed out that India is poor in its management of water resources. As a result, majority of population living in cities are mainly dependent on groundwater. In spite of the municipal water supply people are using private tube wells to supplement their daily water needs.

There are many agencies that look about the WH such as Central Ground Water Board (CGWB established in 1954), Centre for Science and Environment (CSE) and others. Delhi has an annual average rainfall of $611.8 \mathrm{~mm}$ because of poor recharge and heavy extraction of groundwater and consequently the water levels have declined by 8 metres in the past decade. In order to tackle this problem, the Ministry of Water Resources has drawn-up a programme in favor of water harvesting and recharge. The plan of Rs 45 crore has been earmarked for water harvesting in Ninth Plan, out of which the ministry has sanctioned Rs 25 crore for the Central Ground Water Board programme (involving states and user agencies in rural and inaccessible areas). Despite the growing awareness about the benefits of $\mathrm{WH}$; there are many problems associated with water harvesting systems.

Akil, Nathalie \& Joginder (2004) discussed in their article "Rainwater Harvesting, Alternative to the Water Supply in Indian Urban Areas: The Case of Ahmadabad in Gujarat" that water scarcity is a major characteristic of north-western states of India such as Gujarat. The growing water demand in both rural and urban areas has prompted the successive governments of Gujarat to bring water from far-away places which is economically, socially and environmentally unsustainable in the long run. This overall situation has raises the question on use of alternative sources of water in Ahmadabad. Moreover, in Gujarat, the climate is a wet only in sub-tropical regions as the rainfalls have a high intensity. It is known that the state is a water stressed region, since the annual per capita freshwater availability is far below $1.700 \mathrm{~m}^{3}\left(1.321 \mathrm{~m}^{3}\right.$ in 1991) and in coming years the availability of water might drop below the level of $1.000 \mathrm{~m}^{3}$ per annum.

Narain, Khan, \& Singh, (2005) discussed in their article "Potential for Water Conservation and Harvesting against Drought in Rajasthan, India" that Rajasthan is the largest state in India covering an area of 34.22 million hectares (i.e.10.5 per cent) of the country's geographical area, but sharing only 1.15 per cent of water resources. In the last 50 years, a threefold increase in human population and a doubling of livestock populations have put tremendous pressure on the fragile water and land resources of Rajasthan. The objective of 
this study was to assess the traditional and innovative water harvesting and conservation technologies in the context of their potential for drought mitigation throughout the Rajasthan state.

Dinesh, Ankit \& O.P in their article "Rainwater Harvesting in the Water-scarce Regions of India: Potential and Pitfalls" published in 2008 analyzed the impact of water harvesting that is one has to move from the local watershed level analysis to the river basin level analysis, and that basin level impacts are not always aggregates of local impacts. Since the economic, social and environmental values of water are very high in regions that are hited by water shortages, water harvesting interventions etc. Regions that were heavily into irrigated agriculture in the past, supported by good water endowments might continue demanding the large quantities of water for irrigation.

\section{Purpose of the Study}

After in-depth analysis of previous studies; it has been found that rainwater harvesting is very important to remove the scarcity of water. Due to increasing urbanization and population growth; the level of water has decreased down which in turn resulted in a drought like situation. This study is focused on the contribution of rainwater harvesting in the field of agriculture because this sector is the most neglected part of society. In villages there is a little supply of water by the government; so the rural population is fully dependent on water for agricultural purposes as well as to meet their other domestic needs also.

In Ahmadabad region of Gujarat; the intensive untreated human sewage and agricultural activities have caused severe effects on surface water contaminations. Using both primary and secondary data from water samples and community surveys this study analyzes the costs and benefits of $\mathrm{RH}$ in the district. The major costs include the initial construction cost of rainwater harvesting system and the maintenance costs. The major benefits include an increase in household dispensable income, time and energy saved from collecting water, and relief from epidemic droughts.

\section{Water Harvesting in Gujarat}

The technique of WH in Gujarat is very important to reduce the problem of drought and other water related needs such as water for drinking, cooking, industrial and irrigational purposes. All sources of water in state mainly depend upon rainfall in spite of uncertain, erratic and uneven monsoon. The rainfall is decreasing gradually year by year which has resulted in severe drought condition. Moreover, due to increasing population, urbanization, industrialization etc. water is becoming scare in coming years. This has compelled farmers as well as administrative authorities to extract more and more surface water especially for irrigation and drinking purposes. As the state has 19.50 million hectares of land, in which 12.8 million hectare (mh) are cultivable and only 9.5 million hectares are actually cultivated. The irrigated land is only $2.8 \mathrm{mh}$ (i.e. 30 per cent). The average yield in state is low as compared to other states like U.P, Haryana etc. Due to lack of water, there is a need to conserve soil and moisture in rain-fed areas as to obtain a sustainable agricultural production. The implementation of programmes is governed by the Department of Agriculture (GOI, 2011).

The average rainfall in Gujarat varies from 340 to $1900 \mathrm{~mm}$ as compared to the southern region which has more quantity of average rainfall ranging from 750 to $1500 \mathrm{~mm}$. Moreover, Dangs district has the highest average rainfall of about $1900 \mathrm{~mm}$ in comparison to the northern districts that carry 500 to $1000 \mathrm{~mm}$ of average rainfall (Kathiria, 2009). On the other side, the desert area of Kutch has very low amount of rainfall. Due to above reasons; the water harvesting is much more important in Gujarat than other states. Impact of water harvesting especially in rain-fed areas has resulted in achieving state gross domestic product to 10.4 per cent during $10^{\text {th }}$ five year plan as against the targeted GDP to 10.2 per cent. The intensive water harvesting in last 10 years has ultimately resulted an increase in ground water table and irrigated area has increased from 19,30,100 to 27,36,400 hectares(CSRP, 2008). In below table, the Gujarat State Land Development Corporation (GSLDC) under Department of Agriculture has tried their best to show the water management in state in last ten years i.e. from 2002-03 to 2011-12.

Table 3: Water Harvesting Structures in Gujarat

\begin{tabular}{|l|l|l|l|}
\hline 1. & Area covered under watershed & 15.26 & Lakh ha. \\
\hline 2. & Desilting work o village ponds & 8135 & Nos. \\
\hline 3. & Water harvesting structure constructed & 145089 & Nos. \\
\hline 4. & Farm ponds & 60826 & Nos. \\
\hline 5. & Sim Talavadi & 9766 & Nos. \\
\hline 6. & Beneficiaries covered & 7.67 & Nos. \\
\hline 7. & Estimated water harvesting & 200 & Lakh cubic mt. \\
\hline 8. & Estimated increased irrigated area (per year) & 133000 & Hectare \\
\hline
\end{tabular}

Source: GSLDC Report by Mehta \& Chaudhari, 2012 
Now-a-days 70 per cent of water for irrigation and 80 per cent of water for domestic use are drawn from ground water (GSLDC Report, 2012). The districts of Gujarat are classified in three categories for the purpose of water harvesting that are higher, medium and lower. In higher, districts like Rajkot, Jamnagar, Surendranagar, Junagadh, Porbandar, Bhavnagar, Amreli and Kuchchh came as they are the most drought prone districts where recharging of ground water is very high. After that, medium level of water harvesting is being done in Banaskanta, Patan, Mehsana, Ahmedabad, Gandhinagar and Sabarkanthaas they are the less rain-fed areas. Lastly, the Panchmahals, Dahod, Kheda, Anand, Bharuch, Vadodara, Narmada, Surat, Tapi, Valsad, Navsari and Dangs receives very less water harvesting facility as compared to higher and medium level districts because in these districts the average annual rainfall is good. In 2002, the Ahmadabad Urban Development Authority (AUDA) had made rainwater harvesting mandatory for all the buildings covering an area of over 1500 square metres. As according to the rule, one percolation well has become mandatory to ensure ground water recharge as against an area covering more than 1500 square metres (Bouma, 2007).

\section{Water Scarcity - A Phenomenon of the 20th Century}

With time; the rivers flowing through the urban areas have turned-up into the streams of garbage and become dirty where mosquitoes and bacteria breed. To keep pace with the population growth, urbanization and the green revolution the big dams are being seen as the ultimate solution of water woes of a country faced by perennial drought, flood or both. Now-a-days agriculture has become almost dependent on canal water provided by reservoirs. The construction of big dams struck a death knell for the traditional harvesting systems. Harnessing and supplying water became the responsibility of the government. At the time of independence, the rulers of the princely states and the zamindars were the most successful peoples in developing minor irrigation systems through the water harvesting. Thousands of traditional water harvesting systems had declined due to improper want of maintenance and use and as a result-

- Tanks silted up, their embankments were breached and their beds were used for cultivation

- Wells fell into disuse and collected with rubble and garbage

- Deforestation led to floods and soil erosion which destroyed water harvesting structures

- Knowledge of traditional water harvesting systems was not put into practice or passed on to future generations.

But today, even with the large water projects the problem of water famine is still continues. For several decades; the different parts of India have been in the grip of severe drought. Apart from this there exists a serious problem of changes in the natural course of a river. In order to solve these difficulties many big dams have been constructed like Tehri, Narmada and Alamatti.In fact, there is a growing awareness regarding traditional water harvesting systems that it is a better and cheaper alternative to big or small dams. Groups of villages (in some rural areas) have revived small water harvesting systems and are enjoying the benefit.

\section{Need of Rainwater Harvesting}

Water is one of the essential requirements for existence of living beings. To fulfill this, surface and ground water are two major sources of water. Due to over population and higher use of water in urban as well as in rural areas; the water supplying agencies are unable to cope-up the demand from surface sources like dams, reservoirs, rivers etc. However, the rainfall occurrence in country depends upon the monsoon which is limited to about three to four months period ranging around 20 to 30 days (Inderjeet, 2009).Therefore, to augment the natural supply of ground water the artificial recharge to ground water has become an important management strategy. The efforts are basically to locate the natural movement of surface water into ground water reservoirs through suitable civil structures. This practice increases the sustainability of groundwater in the areas where the groundwater levels are declining and water scarcity being experienced. Rainwater harvesting is also necessary because of the following reasons:

- Agriculture continues to be the single largest consumer of water especially in South India and Karnataka.

- Maintains the balance of ecological and hydrological cycle of environment.

- Reduces the private purchase of water from tankers. Tanker water is unreliable in quality and very expensive also.

- RWH encourages water conservation and self-dependence.

- Meeting the domestic and other industrial needs.

Rainwater is a purest form of water though to harvest water is a simple and inexpensive technique. In recent years, it has become compulsory for the new home construction to build proper roofs for rainwater drainage. If an efficient rain water harvesting system is adopted then it assured that there would be a water reserve in case of water shortage. Henceforth, investing in a great rain water harvesting system is well worth foe future use. 


\section{Limitations and Conclusion}

During the acceptance of rainwater harvesting techniques; unlimited problems arise which becomes the disadvantages of rainwater harvesting.

- It requires a large area for the storage of water.

- The cost occurs during the initial construction phase of storage system and no benefit is derived until the system is completed.

- High cost occurred during the retro fitting of an existing property.

- Regular maintenance, cleaning and repair is required for the operation of a successful rainwater collection system.

- The quality of rainwater can be affected by air pollution, insects, and dirt or organic matter.

- The supply of water from a rainwater collection system is not only limited by the amount of rainfall but also by the size of the collection area and the storage facilities.

But in spite of its advantages and disadvantages the process of rainwater harvesting is very important because of the less rainfall. Due to this, various problem arise such as water scarcity, severe droughts etc. Rainwater is a source of water that can provide a cost-effective and alternative source of good quality of water. In addition to this, it also increases the underground level of water. So, rainwater harvesting is the best remedy to reduce the needs of water in present as well as in future.

There are various techniques used to harvest rainwater such as pond, check dam, percolation tanks etc. Among them rooftop rainwater harvesting is the most common technique which is especially used for domestic consumption. It is a simple and cheap technique that requires minimum knowledge and offer many benefits. On the other hand, harvested water can supplement water sources when they become scarce or are of low quality like brackish groundwater or polluted surface water in the rainy season. Similarly, the quality of rainwater may be affected by air pollution, bird's dropping, dirt and organic material etc. Therefore, the regular maintenance like cleaning and repairing of storage structures is required. As well as the treatment before the consumption of water (like filtration, chlorination) is also important. On the other hand, aquifer and subsurface barriers are the two important types of groundwater harvesting which provides water for drinking and irrigation. Recently the Central Ground Water Authority of India has announced the rules regarding rainwater harvesting. As per the new rule, the rooftop water shall only be used for recharging the groundwater. Rainwater harvesting is an ideal solution to solve the water crises.

Rainwater is free from impurities but when it come in contact with the roof then it wash many types of bacteria, molds, algae, protozoa and other contamination in cistern/storage tank, rivers, lakes and wells. But these risks can be minimized by good design and practice of rainwater harvesting. In rainwater collection the artificial recharge also plays a very important role through augmentation of groundwater. It is relevant in areas where the rainfall is seasonal and not uniform throughout the year as well as the quantum of natural recharge is inadequate to meet the increasing demand of water. Overall, it can be said that rainwater harvesting is an important technique to conserve and sustains the supply of groundwater by improving its quality. In Gujarat the quality of underground water is saline which depends on the pattern and quality of land as a result it has become mandatory to adopt.

Several policies have been adopted in favor of rainwater harvesting. In 2002, the Ahmadabad Urban Development Authority (AUDA) had made rainwater harvesting mandatory in new building construction that those covers an area more than 1500 square metres will have to construct one percolation well in order to ensure the ground water recharge. The Government of Gujarat has adopted a solution to solve the water crisis through the Sardar Patel Sahbhagi Jal Sanchaya Yojana popularly known as 40:60 check dam and other methods are also in process such as canal facility in rural areas, tank construction etc. As far as, it has also become mandatory for the all government buildings to adopt the RWH techniques in Gujarat. On the other hand, in Delhi the Ministry of Urban affairs and Poverty Alleviation has made rainwater harvesting mandatory in all new buildings with a roof area of more than 100 sq. $\mathrm{m}$ and in all plots with an area of more than 1000 sq. $\mathrm{m}$.

Similarly, in Mumbai, Rajasthan, Haryana, Utter Pradesh, Kerala, Chennai, Bangalore, Himachal Pradesh and other states of India the Central Ground Water Authority (CGWA) has made it mandatory in new buildings construction those covers an area more than the specified square metres will have to adopted any one type of water harvesting structure whether it would be a percolation tank, recharge pits, shafts or tanks etc. It has also been announced by the CGWA that a rebate of 6 per cent on property tax will be offered as an incentive for implementing rainwater harvesting systems in their own house and that is called a gutter mesh rainwater harvesting system. Many other projects such as Upper Krishna Project in Karnataka, Tehri Project in the hills of Uttar Pradesh and the Krishnaraja Sagar Dam built on the Cauvery in Tamil Nadu were the policies adopted to boost the RWH techniques in 1970s and every year they are modified by the governments of respective states.

During the field survey it has also been noticed that the situation of rural areas in Ahmadabad district is very poor which reflects the whole scenario of Gujarat state. The socio-economic conditions of villagers were very miserable. They neither have any facility from government nor have any other source of income except 
agriculture and for their production they are fully dependent on rainfall. So, in this situation the raindrops are considered as a god who helps them in their worse situation. Therefore, in order to ride out from these prevailing situations, proper steps must be taken in favor of rural people by the government of Gujarat.

- Farmers must be re-encouraged to grow crops that consume less water.

- Better irrigation methods such as drip irrigation and sprinkler system should be given highest priority.

- Adoption of nature-friendly systems of water harvesting such as artificial recharge, sub-surface barriers, rooftop rainwater harvesting etc.

- Policy and measures of harnessing Under-Ground Water must be adopted where the level of underground water is low as compared to acceptable standards.

- Withdrawal of excess water from rivers which helps in avoiding floods and storm water.

- Adoption of check dam in every village because it requires less investment, no ecological disturbance and better utilization of rainwater.

- Those industries which pollute the water resources like rivers and natural streams through the dumping of their industrial waste must be brought in a purview of strict pollution norms. These industries should be heavily taxed and issuance of green card to them.

On the other hand, the traditional water harvesting systems such as tank irrigation, wells (filled with rubble and garbage) and ponds has declined due to improper maintenance and use. These can be maintained and re-used only through the proper maintenance and cleaning. In earlier times the above storage structures were the best method of rainwater collection which in turns maintains the level of underground water. Finally, it can be concluded that the water harvesting is the need of hour today to conserve the water and reduce the problem of water scarcity.

\section{Reference}

[1] Meghashyam. K, Rainwater Harvesting- A New Concept to Utilize Rainwater and Secure the Future (J.M. Jaina \& Brothers: Delhi, 2006).

[2] Jeet. Inder, Rainwater Harvesting (Mittal Publication: New Delhi, 2009).

[3] Allan, J.A. \& Mallat, C, Water in the Middle East: Legal, Political and Commercial Implications (British Academy Press; London, 1995).

[4] S, Patel. A \& L, Shah. D, Water Management- Conservation, Harvesting and Artificial Recharge', New Age International Publishers: New Delhi, 2009).

[5] A Water Harvesting Manual for Urban Areas- Case Studies from Delhi (CSE Publication: New Delhi, 2012).

[6] Average annual rainfall of the states of India (2013), www.rainwaterharvesting.org/urban/rainfall.htm, Accessed on 26/7/2012.

[7] B Arjun, and R, O. Neil, Harvesting Rainwater: Catch Water Where it Falls, Centre for Civil Society, 422-439.

[8] A Water Harvesting Manual, Centre for Science and Environment http://www.cgwaindia.com/suo/home.htm, Accessed on 04/04/2013.

[9] A Akil, P. Nathalie and S. Joginder P (2004), Rainwater Harvesting, Alternative to the Water Supply in Indian Urban Areas: The Case of Ahmadabad in Gujarat, ideas.repec.org/p/hal/journl/hal-00262699.html, Accessed on 22/05/2013.

[10] Narain, P.; Khan, M. A.; Singh, G, Potential for water conservation and harvesting againstdrought in Rajasthan, India. Working Paper 104 (Drought Series: Paper 7), 2005, Colombo, Sri Lanka: International Water Management Institute (IWMI).

[11] K, M. Dinesh, P, Ankit and S, O.P, Rainwater Harvesting in the Water-scarce Regions of India:Potential and Pitfalls', IWMI-TATA Water Policy Program, 2008, 289-314.

[12] Central Ground Water Board, Guide on Artificial Recharge to Ground Water, Prepared by Central Ground Water Board, Ministry of Water Resources, 2011, Government of India, New Delhi.

[13] Kathiria, Rainwater harvesting, a Gujarat Experiment', 2009, deshgujarat.com/../dr-kathiria-writes-rainwater-harvestinga-gujarat..., Accessed on 05/06/2013.

[14] Corporate Social Responsibility Report, 2008-2009, Tata Report, Tata Motors Limited, Jamshedpur.

[15] U, Mehta. P, Profile of Selected Cities of Gujarat', 2012, shodhganga.inflibnet.ac.in/bitstream/10603/.../08_chapter\%204.pdf, Accessed on 01/12/2012

[16] J. Bouma, J, Soest, D.V and Bulteb, E, How Sustainable is Participatory Watershed Development in India?', 2007, Agricultural Economics 36, 13-2- 50.

[17] M, Murase Edited by K. Matsushita, Sustainable Water Strategies for New Development Patterns - Environment in 21st Century and New Development Patterns' in English, 1999.

[18] Tanwar, B.S, Water Related Problems of Haryana- Need for Science and Technology Inputs for Management and Geohydrology', 2003 Indian Geological Congress, pp. 29-38. 